\title{
Are Local Food Systems Vectors of Sustainable Choices?
}

\author{
Corina Ene \\ Faculty of Economic Sciences, Petroleum-Gas University of Ploieşti, Bd. Bucureşti 39, 100680, Ploieşti, \\ Romania \\ e-mail: ecorina@upg-ploiesti.ro
}

DOI: 10.51865/EITC.2021.03.07

\begin{abstract}
In the last few years, but even more so given the context the COVID-19 pandemic, a large series of global and local changes have occurred in all areas of life, including the way food is perceived and procured. The orientation towards local food as a preferred choice has gained more followers which are interested in economic, social and environmental effects of the way the world uses all kinds of resources to meet its nutritional needs. Local food involves a special kind of food systems approach in terms of determining factors and resulting implications for all actors involved. The paper deals with emphasizing different aspects of local food systems, including both agri-food producers and consumer's drivers together with the effects of rethinking the way people choose to procure their food. The link to sustainable development is clearly highlighted using the multiple implications of this agri-food system upon different sectors and dimensions.
\end{abstract}

Keywords: short food supply chains, local food; agri-food producer; food consumer; sustainability.

JEL Classification: $Q 18 ; P 46 ; Q 01$.

\section{Introduction}

The challenges posed by sustainable development, food security and safety and the Covid crisis have determined the metamorphosis of the global food system (Popescu et al., 2017; Drăgoi et al., 2018; Zaman et al., 2019). Nowadays, short food supply chains (SFSCs) are becoming more and more a viable alternative to globalized food supply chains and tend to play an increasingly significant role within food supply mechanisms and systems. Many researchers and practitioners underline their numerous economic, social, environmental, nutritional and health benefits for both producers and consumers (Djokoto et al., 2015; Tanasă, Brumă and Doboş, 2015; Boboc et al., 2017; Khan et al., 2021; Qin et al., 2021), as they manage to connect final consumers (especially younger generations) to small local agri-food producers.

At present, the expression "local food" has not acquired a unanimously accepted definition, but various approaches have in common the geographic dimension. This is expressed by the fact that local food available for consumers is a result of a SFSC, which means an agri-food producer/farmer sells food to a consumer located at a short distance, involving a minimum number of intermediaries (RNDR, 2015). 
Most researchers and food systems advocates approached the meaning and particularities of SFSCs based on different criteria related to the number of intermediaries, physical distance, and organizational arrangements, but supplementary criteria can also be taken into consideration, such as the level of compromise adopted either by consumers or producers and the type of individual or collective initiators (Jarzębowski, Bourlakis and Bezat-Jarzębowska, 2020).

Thus, "local" can be regarded by opposition to "global" or "national". Besides, the significance of local food systems should also take into consideration several coordinates such as: population density, the surface of the urban / rural area, the typology of the localities, road infrastructure, but also the purpose of the defining entity (Tanasă, 2015).

Nevertheless, researchers identified some difficulties in practical delimitation of the term created by, for example: the origin of food used in feeding the livestock or poultry; the origin of certain food ingredients or additives; the complicated logistics for food that is transported back to the producer after processing stages which took place in a different region.

This paper brigs into attention the key-points of local food systems as possible vectors of sustainability, based on their effects and implications on all parties involved and taking into consideration consumer's perspectives on local food.

\section{Local Food Systems - Types and Approaches}

Obviously, direct sales from the original producer to customer are the shortest supply chain. By eliminating intermediaries, local food systems bring together production, processing, marketing and consumption of food in a geographical area of relatively small size, which impacts all actors involved.

A more in-depth approach is considering SFSCs as functioning on three levels (Jarzębowski, Bourlakis and Bezat-Jarzębowska, 2020):

1. local food systems; these are located in rural areas, close to a major city, and operate as processors/ retailers in order to increase their revenues. These types of actors have been the first promoters of sustainable/organic farming and production methods and their practices have often been duplicated by large producers/retailers.

2. hyper-local food systems; also located in rural areas close to a town, involved in production, processing, and vending. This category includes traditional urban farming activities benefiting from using high technology, but also broader initiatives integrated in the circular bio-economy.

3. ultra-local food systems; much more limited in terms of functionality, these activities refer to cover gardens or greenhouses grown as a hobby, providing limited quantities of home grown food available for sharing with neighbors, or for selling in small markets. Food is produced within households by peasants and farmers who are proud of their agricultural activities (Brădățan and Pencea, 2015).

As far as sales organization is concerned, the increasing demand for fresh, local products mostly fruits and vegetables - has led to diversification of sales opportunities. A restrictive approach relates the concept of "local food" almost exclusively to direct sales, i.e. face-to-face interaction between farmers and food consumers. Obviously, it stands to reason that direct sale continues to be the most significant part of local food capitalization, but currently the array of sales opportunities is much more extended. Thus, different models in providing local food include:

o the Community supported agriculture (CSA) model - a partnership between consumers and food producers in which members purchase a CSA share from the farmer and in return receive (usually, weekly) a certain quantity of seasonal produce throughout the farming season; 
o direct on-farm sales;

o "basket" delivery systems;

o direct sales within own stalls in open-air markets;

o itinerant sales using farmer's own means of transportation and stationary stalls;

o distribution through local food supply chains which include restaurants, shops and other food services;

o sales from local small growers to institutions (including hospitals and education units);

o direct or online sales through producers' groups/associations;

o online sales through farmer's own website/social media page;

o online sales through food hubs (defined as organizations that facilitate the distribution of primarily locally grown source-identified food from farmers to customers (Krejci et. al, 2015).

Not all these approaches are sales solutions suitable for each agri-food producer, but these models can inspire sales schemes adaptation to its own specifics.

\section{Multilateral Implications of Shifting towards Local Food on Sustainability}

\section{The link between SFSCs and sustainable development}

SFSCs exist in many forms across the globe, usually involving a limited number of intermediaries between the agri-food producer and the consumer, tending to focus on local produce and close cooperation between the people involved. SFSCs have the potential to bring together producers and consumers and to increase added value for farmers in the food chain. It can improve farm incomes, increase competitiveness and support environmental sustainability, provided the chain is organized efficiently and costs are accurately calculated. Improving collaboration between farmers, agricultural cooperatives, food processing operators, consumers and other parties involved in short supply chains can increase this potential and provide mutual benefits (PEI-AGRI, 2021). In this way, the people involved are given the opportunity to develop new products and processes to add value and improve the range of products available to consumers. It can also contribute to greater efficiency in logistics and distribution, strengthen food chains and open up new markets.

As many researchers and practitioners highlighted, the local food approach and, in particular, the SFSC model mean significant changes in several areas of interest for all parties involved.

The main characteristic of SFSCs - reducing the distances over which food is transported provides numerous favorable consequences on several interconnected directions (RNDR, 2015; Augère-Granier, 2016; FAO, 2019):

1. economic benefits: savings on the costs of transport; increasing local producers' share of profit; easier identifying of raw materials sources and traceability; discount of consumer expenses; job creation in agriculture; generating higher local employment in food production and connecting areas: food processing, distribution, marketing, sales and services; re-launch of local entrepreneurial activity; better opening of local markets; increasing the income of the local community; economic recovery in disadvantaged areas; short storage periods; less packaging; promoting local tourism/agritourism;

2. environmental benefits: keeping "food miles" at minimum means: reduction of greenhouse gas emissions; minimizing energy use and carbon footprint; encouraging ecological production methods; encouraging respectful behavior towards environment; generating less waste (due to low storage period, less packaging and superior valorization);

3. social benefits: a lower burden of rural infrastructure; reducing traffic congestion; increasing road safety; creation and strengthening the connection between producers and consumers; increased interaction, knowledge and mutual understanding between consumers and producers; 
establishing relationships of immediate trust and traceability; creating a basic level of food sovereignty; supporting social cohesion and community spirit (an increased trust and sense of community), increased recognition of producers; enhanced social and professional inclusion for all parties involved.

4. food quality and health benefits: superior taste/aroma; cleaner products in terms of food pollution (as lesser amounts of pesticides or fertilizers are used); health benefits derived from less processing, higher freshness, improved allergies; higher nutritional value.

Additional benefits of small farming systems, regarded as key actors for local food security were identified, such as: the possibility of free of genetically modified organisms, agrobiodiversity preservation and the high resilience to climate change (Altieri, 2009; Stancu, 2012).

Local food systems can be strongly linked to the concept of food sovereignty, which emphasizes farmers' access to all necessary resources while focusing on local autonomy, local productionconsumption cycles, and farmer-to-farmer networks (Altieri, 2009). In this regard, agroecology is playing an important role altogether with its drivers, decision factors and decision makers in a complex economic, social, cultural, and political context.

In order to underline the strong connection between food systems and other areas, and mainly the interplay of economic and social dimensions, the concept of "social embeddedness" related to direct agricultural markets was used (Hinrichs, 2000). Furthermore, correlation and causality between local food systems and social welfare must be subject to future studies (Kaika and Racelis, 2021) due to their complex inter-determination.

Another significant correlation can be established between local food systems and the scope of reducing food waste at all levels. During the last years, food waste has been considered a globally relevant issue, having a significant impact upon different areas: society, economy, and environment. Many international and regional reports underlined the magnitude and the consequences of this challenge, underlining the need for efficient prevention measures and actions. The Food and Agriculture Organization 2019 report on food loss and food waste (FAO, 2019) indicated earlier estimation according to which, annually, about 1.3 billion tons of food corresponding to one-third of edible parts of food produced for human consumption was lost or wasted, globally. In this context, the European Union orientation follows the global trends and aims to support efforts to halve food waste by 2030. In Romania, food waste amounts to 6,000 tons per day and it is estimated that the highest percent (49\%) is generated in households from urban areas, while rural communities use traditional methods of recovery of food waste in the household (INSP, 2019). As a consequence, we may admit that local food systems have a positive impact upon reducing or limiting food waste.

The link between SFSCs and sustainable development can be analyzed based on different dimensions which are closely interconnected, given its synergies with other sectors (Jarzębowski, Bourlakis and Bezat-Jarzębowska, 2020). In fact, all above mentioned implications are obviously correlated with sustainable development aims and principles. In particular, SFSCs can be regarded as a means to restructure the agri-food sector in order to develop sustainable farming methods (RNDR, 2015).

Recent global context generated by the Covid-19 pandemics brought to attention multiple changes and repositioning in all sectors of life, including agri-food, food procurement and food consumption. According to Campbell (2021), COVID-19 had the effect of increased media and public attention on food systems and affected perspectives on local food production and its role in communities during public health emergencies, but it is also important that this attention moves to long-term planning and food systems development.

In this context, a recent Ernst \& Young market study highlighted several changes in terms of purchasing specific details (EY, 2020): 
o goods quality become the main factor, with the largest increase in importance during the pandemic (66\%), followed by price;

0 the volume of purchases increased, with a migration to local products to the detriment of imports;

o over a third of respondents preferred to order food online with home delivery.

The global pandemic exposed the flaws (fragility and instability) of global supply chains and caused the increasing interest in local food, making the need for local food systems more relevant to communities across the world (Kaika and Racelis, 2021; Khan et al., 2021).

A research conducted in China in 2020 showed that strengthening urban-rural linkages and fostering local food production are prerequisites of more resilient local food systems (Fei, Ni and Santini, 2020), as a lesson to be learned from the recent global health crises.

In this specific context, with high probability, consumers will continue to turn to buying more local products considering the need to trust and support local producers, and retailers will rely less on imports. In order to avoid global supply shortages, favoring the businesses of local producers by creating more SFSCs would mean a reversal of globalization, which would need the government and NGO's support by ensuring access to innovation, financial capital and guarantees.

Researchers in the last decade draw the attention on the fact that sustainable agriculture can be implemented only through significant structural changes which include technological innovation, farmer-to-farmer networks, and farmer-to-consumer solidarity (Altieri, 2009). The shift toward more sustainable food practices can be regarded as a necessity, whereas local food consumption is an example of a sustainable practice that needs to be adequately promoted (Jung, Ho Shin and Dougherty, 2020).

\section{The European Union position on short food supply chains}

In the European Union (EU), one of the principles of the single market is to offer consumers the opportunity to choose from a wide range of products, including agricultural products, in accordance with their needs and preferences. Therefore, policies should not impose one type of agricultural production supply instead of another. However, at the same time, the Common Agricultural Policy (CAP) allows producers to meet different consumer requirements and requires them to produce in accordance with environmental and food safety standards. Furthermore, the CAP supports cooperation between actors in the supply chain and encourages agricultural production based on local circuits and short supply chains which promote local consumption and stimulate the local economy (Kneafsey et al., 2013).

Since, on average, $15 \%$ of EU farms sell more than half of their production directly to consumers, we can assume that in the last decade, SFSCs and local markets developed in all EU countries, both in rural and urban areas (Augère-Granier, 2016).

The EU rural development policy 2014-2020 put significant emphasis on SFSCs by providing producers the opportunity of benefiting from measures co-financed by the European Agricultural Fund for Rural Development. Also, as a sequel, supporting local actions is a notable feature of current rural development programmes, which are the main instruments of the CAP support for rural development for 2021-2027 interval (European Union, 2021).

Nevertheless, most small farmers have little knowledge of the instruments meant for their support, they do not know how to access them or do not manage the bureaucratic process in order to benefit from European funding. This situation requires more measures to effectively support small producers, allowing them access to funding and knowledge to ensure a proper role within the food market and facilitate their relations to consumers. Despite the difficulties, the local food approach can be already considered a success in most European Union countries and 
lately enjoys increased attention also in Romania, both among agri-food producers and food consumers (RNDR, 2015).

\section{Food Hubs - Viable Solutions to Traditional Agriculture's Challenges}

Traditionally, farmers can choose to sell their products to resellers, or to face a high risk of remanent unsold goods after making considerable efforts to sell it directly in the markets or to deliver it to loyal customers.

The concept of "Food Hub" was developed in the United States - and has become an important component of the US Department of Agriculture's (USDA) initiatives - as an alternative to the classic systems of capitalization of agricultural production obtained within small farms (Scarlat, 2020). USDA initiatives include funding and investments in research and education, mainly for young farmers. The USDA defines a food hub as a "centrally located facility with a business management structure facilitating the aggregation, storage, processing, distribution, and/or marketing of locally/regionally produced food products". (Community-Wealth, 2021)

A definition of a regional food hub states that it "is a business or organization that actively manages the aggregation, distribution, and marketing of source-identified food products primarily from local and regional producers to strengthen their ability to satisfy wholesale, retail, and institutional demand" (Barham et al., 2012).

The term "food hub" applies to a wide range of operations, from CSAs to virtual markets linked to a physical location for delivery, developed on the internet and allowing buyers and producers to connect. Food hubs work on the principle that "individual farms cannot survive on their own" (Scarlat, 2020) and are created by the associations of individual farmers. These food centers bring a solution worthy of consideration to all the classic challenges, whereas allowing farmers to efficiently collaborate in marketing and distribution. Besides direct economic benefits deriving from investing in local economies, food hubs also support a sense of regional pride and solidarity (Scarlat, 2020), and have broad implications on community wealth (Fig.1.).

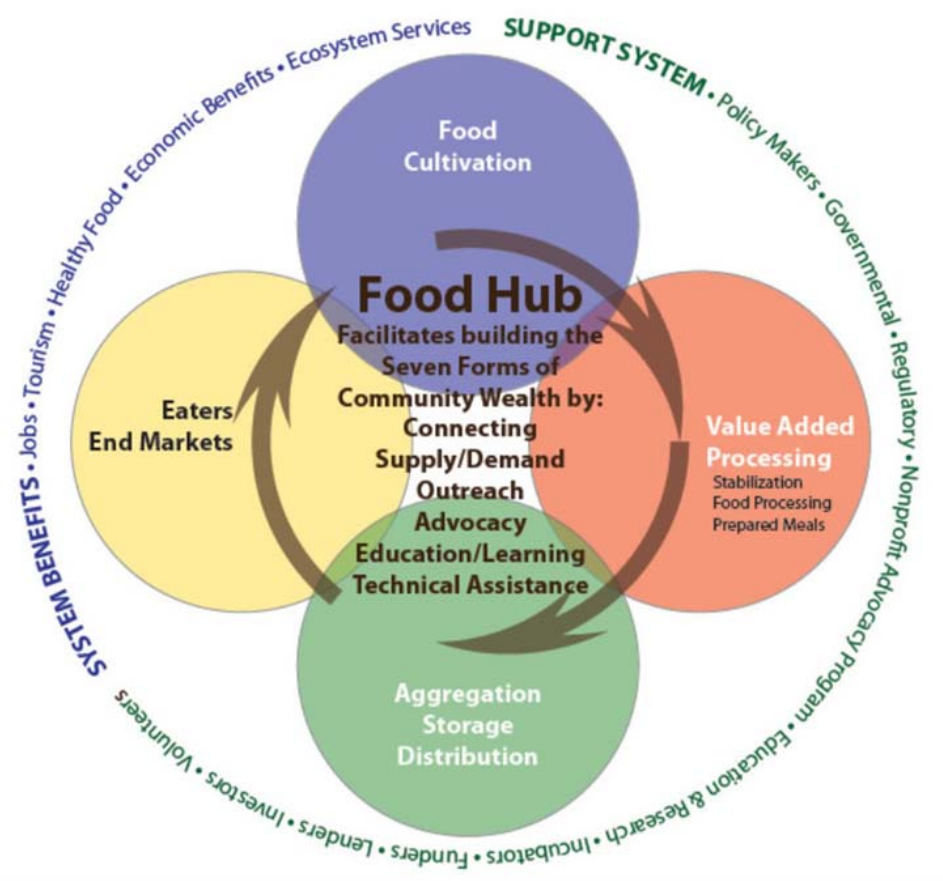

Fig. 1. Food hubs implications on community wealth

Source: Great lakes Food Hub Network, USA, https://community-wealth.org/strategies/panel/urbanag/index.html 


\section{Local Food in Consumer's Perspective}

Statistics showing that food can travel up to 2400 kilometers until it reaches one's plates made many consumers prefer dramatically reduced distances reaching up to 70 kilometers on average (Brădățan and Pencea 2015).

Understanding the buying habits and the reasons for choosing to buy local food products is the base for developing and implementing appropriate policies and marketing strategies to promote local food purchases, which can stimulate healthier and more sustainable food choices (Nicolosi et al., 2019). Consumption of local food products is gaining popularity, especially among urban consumers, who are socially active and well connected to new media through the Internet (Brădățan and Pencea 2015)

More research shows that the choice to consume local products reflects the need of the modern consumer to satisfy qualitative requirements, subjective well-being, and respect for socioenvironmental balance (Nicolosi et al., 2019). The value of local products includes, besides the economic dimension, identity and essence of a community living in a territory, its customs, habits and traditions (Nicolosi et al., 2019). A study about Swedish consumers shows that during purchasing of local cheese, customers have a loyalty point at the point of sale, follow the advice of the seller, are attentive to the reputation of the product, have a strong connection with the territory and wish to contribute to supporting the local economy (Nicolosi et al., 2019).

The results of an US study on financial and social drivers of food hub commerce and participation suggest that social factors such as desire to support the community can be more motivational than financial factors. (Krejci et al., 2015)

A research oriented towards Romanian consumers (Chiciudean, 2014) revealed the following main conclusions:

o the local origin of the food is very important;

o the local product is associated with the certification of "traditional product";

o the local product is considered fresh, tasty and authentic;

o there is an increase in interest in specialty stores to the detriment of supermarkets and hypermarkets in the case of local food purchases;

o domestic products prevails in consumer preferences over imports;

o the country of origin of the food is less important than its price or ingredients.

A related study brought into attention the concept of "ethnocentrism" regarded as a natural tendency of consumers to judge reality from their own cultural perspective, considering other options as inferior. In this context, regional ethnocentrism reflects the importance attached to products originating from one's own region rather than the preference for any regional products. After analyzing the degree of ethnocentrism among the Romanian consumers (Chiciudean et al., 2016), the sociodemographic profile was built for the two resulting segments of consumers: ethnocentric consumers and non-ethnocentric consumers. No significant differences could be noticed in terms of purchasing patterns habits regarding local food products, as both consumer groups appreciated this food category (Chiciudean et al., 2016; Stancu, 2016).

A scientific investigation among US college students' beliefs highlighted a series of facilitators of local food consumption (Jung, Ho Shin and Dougherty, 2020): availability of local food, clear advertisement, knowledge of local food, convenience, social support, lower cost, previous experience, state pride, friendly environment, appreciation for farmers, and connection with farmers.

The results of a study about the purchase intentions toward the local food distribution showed that transparency, support for local, and labeling determine purchase intentions and "shapes brand love" (Kumar et al. 2021). 
On the other side, consumers identified several disadvantages and barriers of local food consumption, including limited variety, higher prices, less varied diet, lack of information, lack of availability, and inconvenience (Jung, Ho Shin and Dougherty, 2020).

A critical view of local food system in terms of food consumer values underlines that the local food buyer behavior is not necessarily morally superior to alternative options (Ferguson and Thompson, 2021), advising to not absolutize the moral benefits of locavorism (defined as the practice of eating food that is produced locally) despite of its advantages.

A recent research using a values-beliefs-attitude model of local food consumption in China and Denmark concluded that beliefs are positively related to attitudes towards and intentions to buy local foods, while collectivistic values are positively related to locavorism (Zhang, Grunert and Zhou, 2020).

\section{Concluding Remarks}

Higher consumers' requirements regarding health and correct nutrition mostly implying diets rich in fruits and vegetables have led to increasing demand for local food sold by specific markets. These concerns of modern, health-conscious consumers open up many possibilities for the direct sale of local food products, leading to the diversification of sales channels.

By choosing locally grown/produced food, consumers are more and more convinced that food: (a) will be fresher, (b) will travel much less reducing pollution, (c) will be sold at fairer prices for the producer, (d) will ensure direct links to farmers and country life, (e) will help to add a more personal touch by knowing where food comes from, how/by whom it was grown.

Local agriculture - meaning obtaining agricultural products and food in order to sell it (directly or through specialized structures/hubs) in an area close enough to the area of culture - is certainly a concept which tends to significantly change the way consumers obtain food.

Functioning in parallel to conventional food chains, SFCS' growing importance seems to be related to the increasing concern of food quality from both the production and the consumption actors.

Looking at their benefits of we may draw the conclusion that SFSCs support the sustainability approach in multiple ways, as they meet the societal demands about food quality while reducing the social and environmental impact of agriculture conventional practices.

For these reasons, encouraging and practically supporting such initiatives can be seen as a necessity in the actual global context. Development of SFSC structures implies helping them cope with economic, technical and regulatory shortcomings and barriers they have to face. It means favoring the creation of agri-food cooperatives, their access to modern production technologies and bringing consumers closer to the local food markets.

Certainly, the current study reviewed a series of global and regional trends, but particular, more specific analysis should be conducted in order to establish the achievability of local food systems in terms of sustainability. Meanwhile, we can consider the hypothesis that humanity could return to local food systems that have fed much of the planet for centuries, mostly rooted in traditional small-scale agriculture, and that are socially and ecologically friendly, respecting biodiversity and sustainability principles. Post Covid-19 pandemic era could mean focusing on sustainability in every sense, and SFSCs could be a part of the solution.

\section{References}

1. Altieri, M. A., 2009. Agroecology, Small Farms, and Food Sovereignty, Monthly Review, An Independent Socialist Magazine, Volume 61, Issue 03 (July-August). Available through: 
https://monthlyreview.org/2009/07/01/agroecology-small-farms-and-food-sovereignty/[Accessed 1 June 2021]

2. Augère-Granier, M.L., 2016. Short food supply chains and local food systems in the EU, European Commission, Rural Development. Briefing September 2016. Available through: https://ec.europa.eu/info/food-farming-fisheries/key-policies/common-agricultural-policy/ruraldevelopment [Accessed 10 May 2021]

3. Barham, J., Tropp, D., Enterline, K., Farbman, J., Fisk, J. and Kiraly, S., 2012. Regional Food Hub Resource Guide. U.S. Dept. of Agriculture, Agricultural Marketing Service. Washington, DC. April 2012.

4. Boboc, D., Popescu, G., Stoian, M., Lădaru, G. R. and Petrache, D. C. (2017). Best practices for integrating the Romanian small farmers into the agri-food chain. The Amfiteatru Economic Journal, 19(44), 315-315.

5. Brădățan, T, Pencea, R., 2015. Promovarea și marketingul produselor din gospodăriile țărănești. Asociația Hosman Durabil Hosman. Available through: https://moara-veche.ro/wpcontent/uploads/2016/09/studiuHosman.pdf [Accessed 1 June 2021]

6. Campbell, C. G ., 2021. The impact of COVID - 19 on local government stakeholders' perspectives on local food production. Journal of Agriculture, Food Systems, and Community Development, 10(2), 71-88, https://doi.org/10.5304/jafscd.2021.102.035 [Accessed 15 May 2021]

7. Chiciudean, I. D., 2014. Produsele locale și percepția consumatorilor asupra acestora. Rezumat al tezei de doctorat Uuniversitatea de Ştiinţe Agricole ;i Medicină Veterinară, Cluj-Napoca.

8. Chiciudean, G. O., Mureşan, L. C., Chiciudean, I. D., Arion, F. H.; Oroian, C. F. and Harun, R., 2016. Influenţa etnocentrismului asupra comportamentului consumatorului de produse alimentare locale. Review of Management \& Economic Engineering . 2016, Vol. 15 Issue 4, p. 668-679.

9. Community Wealth, 2021. Overview. Local Food Systems. Available through: https://communitywealth.org/strategies/panel/urban-ag/index.html [Accessed 10 May 2021]

10. Djokoto, J., Afari-Sefa, V. and Addo-Quaye, A. (2015). Vegatable supply chains in Ghana: production constraints, opportunities and policy implications for enhancing food and nutritional security. Int J Trop Agric. 2015;33(3):2113-121.

11. Drăgoi, M. C., Andrei, J. V., Mieilă, M., Panait, M., Dobrotă, C. E. and Lădaru, R. G. (2018). Food safety and security in Romania-an econometric analysis in the context of national agricultural paradigm transformation. Amfiteatru Economic, 20(47), 134-150.

12. Ernst \& Young (EY), 2020. Comportamentul consumatorului român în contextul COVID-19. Available through: https:/www.ey.com/ro ro/covid-19/comportamentul-consumatorului-roman-incontextul-covid-19-[Accessed 15 May 2021]

13. Fei, S., Ni, J. and Santini, G., 2020. Local food systems and COVID-19: an insight from China, Resources, Conservation and Recycling, Volume 162, https://doi.org/10.1016/j.resconrec.2020.105022.

14. Ferguson, B. and Thompson, C., 2021. Why Buy Local?. J Appl Philos, 38: 104-120. https://doiorg.am.e-nformation.ro/10.1111/japp.12459

15. Food and Agriculture Organization (FAO), 2019. The State of Food and Agriculture 2019. Moving forward on food loss and waste reduction. Rome.

16. Hinrichs, C.C., 2000. Embeddedness and local food systems: notes on two types of direct agricultural market. Journal of Rural Studies 16 (2000) 295-303, Elsevier.

17. Institutul Național de Sănătate Publică (INSP), 2019. Analiza de situație. Available through: https://insp.gov.ro/sites/cnepss/wp-content/uploads/2019/10/Analiza-de-situatie-2019.pdf [Accessed 15 May 2021]

18. Jarzębowski, S., Bourlakis, M. and Bezat-Jarzębowska, A., 2020. Short Food Supply Chains (SFSC) as Local and Sustainable Systems. Sustainability. 2020; 12(11):4715. https://doi.org/10.3390/su12114715

19. Jung, S. E., Ho Shin, Y and Dougherty, R., 2020. A Multi Theory-Based Investigation of College Students' Underlying Beliefs About Local Food Consumption, Journal of Nutrition Education and Behavior, Volume 52, Issue 10, pp. 907-917, https://doi.org/10.1016/j.jneb.2020.07.002

20. Kaika, A. and Racelis, A., 2021. Civic agriculture in review: Then, now, and future directions. Journal of Agriculture, Food Systems, and Community Development, 10(2), 551-572. https://doi.org/10.5304/jafscd.2021.102.030

21. Khan, S. A. R., Razzaq, A., Yu, Z., Shah, A., Sharif, A. and Janjua, L. (2021). Disruption in food supply chain and undernourishment challenges: An empirical study in the context of Asian countries. Socio-Economic Planning Sciences, 101033. 
22. Kneafsey, M., Venn, L., Schmutz, U., Balázs, B., Trenchard, L., Eyden-Wood, T. Bos, E., Sutton, G. and Blackett, M., 2013. Short Food Supply Chains and Local Food Systems in the EU. A State of Play of their Socio-Economic Characteristics. Editor(s): Santini, F. and Gómez y Paloma, S., European Commission, Luxembourg: Publications Office of the European Union.

23. Krejci, C., Stone, R., Dorneich, M. and Gilbert, S. 2015. Analysis of Food Hub Commerce and Participation Using Agent-Based Modeling: Integrating Financial and Social Drivers. 58. $10.1177 / 0018720815621173$.

24. Kumar, S., Murphy, M., Talwar, Shalini, Kaur, P. and Dhir, A., 2021. What drives brand love and purchase intentions toward the local food distribution system? A study of social media-based REKO (fair consumption) groups, Journal of Retailing and Consumer Services, Volume 60, https://doi.org/10.1016/j.jretconser.2021.102444.

25. Nicolosi, A., Laganà, V.R., Laven, D., Marcianò, C. and Skoglund, W., 2019. Consumer Habits of Local Food: Perspectives from Northern Sweden. Sustainability, 11, 6715; 10.3390/su11236715 www.mdpi.com/journal/sustainability

26. Qin, X., Godil, D. I., Sarwat, S., Yu, Z., Khan, S. A. R. and Shujaat, S. (2021). Green practices in food supply chains: evidence from emerging economies. Operations Management Research, 1-14.

27. Parteneriatul European pentru Inovare privind productivitatea şi durabilitatea agriculturii (PEIAGRI). Inovarea în lanțurile scurte de aprovizionare. Available through: https://www.rndr.ro/documente/brochure EIP short food supply chains RO web.pdf [Accessed 1 June 2021]

28. Popescu, G. H., Nicoale, I., Nica, E., Vasile, A. J., and Andreea, I. R. (2017). The influence of landuse change paradigm on Romania's agro-food trade competitiveness-An overview. Land Use Policy, 61, 293-301.

29. Scarlat, M., 2020. Food hubs - soluția de valorificare a producțiilor de la micii fermieri, AGROTRENDS. Available through: https://agrotrends.ro/interviuri/food-hubs-solutia-americanilorde-valorificare-a-productiilor-de-la-micii-fermieri/ [Accessed 15 May 2021]

30. Stancu, A, 2012. Correlation between Food Quality and Preservation Methods. The USV Annals of Economic and Public Administration, 12(2(16)), 43-49.

31. Stancu, A, 2016. Correlations and Patterns of Food and Health Consumer Expenditure. In J. V. Andrei, ed. 2016. Food Science, Production, and Engineering in Contemporary Economies. Hershey: Information Science Reference (an imprint of IGI Global). pp.44-101. https://doi.org/10.4018/978-1-5225-0341-5.ch003.

32. Reţeaua Naţională de Dezvoltare Rurală (RNDR), 2015. Lanțul Scurt Alimentar. Publicaţia Tematică Nr. 29, An II.

33. Tanasă, L., 2015. Lanţuri logistice agroalimentare scurte sustenabile pentru dezvoltarea inovativă a turismului şi a comunităţilor rurale din ţările emergente, in Dămăceanu, R.Cătălin \& Haller, A.-P. (coord.) Crizele şi pieţele emergente, Pro Universitaria, Bucharest.

34. Tanasă, L., Brumă, I.-S., Doboş, S., 2015. Contribuţia lanţurilor scurte de aprovizionare în dezvoltarea micilor producători agroalimentari locali. Studiu de caz: județul Harghita, in Economie agrară şi dezvoltare rurală - realităţi şi perspective pentru România, Institutul de Cercetare pentru Economia Agriculturii şi Dezvoltării Rurale, Noiembrie 2015, Bucharest.

35. Zaman, G., Panait, M. C., Voica, M. C. and Ene, C. (2020). Corporate Social Responsibility in the Agri-Food Sector. In Recent Advancements in Sustainable Entrepreneurship and Corporate Social Responsibility (pp. 37-68). IGI Global.

36. Zhang, T., Grunert, K.G. and Zhou, Y., 2020. A values-beliefs-attitude model of local food consumption: An empirical study in China and Denmark, Food Quality and Preference, Volume 83, https://doi.org/10.1016/j.foodqual.2020.103916. 